\title{
SENAM HAMIL, DURASI TIDUR DAN DENYUT JANTUNG JANIN
}

\author{
Ina Handayani, Pudji Suryani \\ Poltekkes Kemenkes Bandung, Jl. Pajajaran No.56, Kota Bandung, Jawa Barat 40171 \\ Email: inaumialyafaris@gmail.com
}

\section{PREGNANCY EXERCISE, SLEEPDURATIONAND FETAL HEART RATE}

\begin{abstract}
Some discomfort often occurs during the third trimester such as lower back pain and decrease sleep duration. Sleep disturbances experienced by women in the third trimester of pregnancy, This is causing the problem of sleep disturbance at night, waking up from sleep at midnight and difficult to sleep especially at the end of pregnancy. At this time, pregnant women have experience anxiety, so they have depression and difficult to sleep and influence the physical condition including fetal heart rate. The aim of this study was to know the effect pregnancy exercise of sleep duration and fetal heart rate in third trimester pregnant women. This study used pre experiments with quasi experiment by pre and post test design without control. The number of samples was 12 respondent. Research was conducted in Puskesmas Gang Kelor for 4 week. Statistical tests in this study used wilcoxon and $t$-test. The results showed that pregnancy exercise influence sleep duration, $(p=0.01)$ ) and fetal heart rate ( $p=0.008)$. Health works are expected to disseminate the implementation of health for pregnancy exercise for pregnant women and families.
\end{abstract}

Keywords: pregnancy exercise, sleep duration, fetal heart rate

\begin{abstract}
Abstrak: Pada trimester ketiga terdapat ketidaknyamanan yang sering timbul antara lain nyeri punggung bawah, penurunan durasi tidur. Gangguan tidur saat kehamilan ini merupakan masalah yang menyebabkan ibu terbangun saat tidur tengah malam dan berlanjut mengalami sulit tidur terutama di akhir kehamilan. Pada masa itu ibu hamil sering mengalami kecemasan yang menyebabkan penurunan durasi tidur ibu hamil dan berpengaruh terhadap kondisi fisik ibu hamil. Tujuan penelitian ini adalah untuk mengetahui pengaruh senam hamil terhadap durasi tidur, ketidaknyamanan dan kondisi fisik ibu hamil trimester ketiga di Puskesmas Wilayah Bogor Barat. Penelitian ini menggunakan rancangan pre-eksperimen one group pre-test post-test. Pengambilan sampel dilakukan secara multistage sampling yang akan dilakukan terhadap 12 responden. Penelitian dilakukan di wilayah Puskesmas Gang Kelor. Variabel diukur menggunakan instrumen pre-test post-test sebelum dan setelah diberikan perlakuan senam ibu hamil. Uji statistik menggunakan uji one sample t test dan uji Wilcoxon. Hasil penelitian menunjukkan ada pengaruh senam hamil terhadap durasi tidur ibu hamil $(p=0,01)$ dan denyut jantung janin $(0,00)$.
\end{abstract}

Kata Kunci: senam hamil, durasi tidur, denyut jantung janin

\section{PENDAHULUAN}

Kehamilan merupakan suatu transisi antara kehidupan sebelum dan sesudah kelahiran anak. Perubahan ini dipertimbangkan sebagai periode menjalani proses persiapan baik secara fisik maupun psikologi (Dietz, 2007). Secara fisik terdapat perubahan fisiologis yang terjadi selama kehamilan, dan hal ini mempunyai dampak yang bersifat patologis bagi wanita hamil. Pada trimester ketiga, keluhan yang diakibatkan oleh pembesaran perut, perubahan anatomis dan perubahan hormonal akan menyebabkan munculnya keluhan pada ibu hamil (Venkata \& Venkateshiah, 2009).

Gangguan tidur sering dialami ibu hamil walaupun kehamilan normal (Santiago J.R, 2001), dan sebanyak $97 \%$ ibu hamil pada trimester ketiga mengalami gangguan tidur. Gangguan tidur ini menimbulkan depresi dan stres yang berpengaruh terhadap janin yang dikandungnya. Kesulitan tidur pada ibu hamil disebabkan rasa cemas berkaitan perubahan fisik dan psikologinya tersebut 
(Sharma S, 2004). Kecemasan meningkatkan kadar norepinefrin dalam darah melalui stimulasi sistem saraf simpatis. Perubahan kimia ini menyebabkan kurangnya waktu tidur tahap IV NREM dan tidur REM serta lebih banyak perubahan dalam tahap tidur lain dan lebih sering terbangun (Kozier et.al, 2010).

Penurunan durasi tidur pada ibu hamil dapat membuat kondisi ibu hamil menurun, konsentrasi berkurang, mudah lelah, badan terasa pegal, tidak mood bekerja, dan cenderung emosional. Gangguan tidur menimbulkan depresi dan stres yang berpengaruh pada janin yang dikandungnya. Stres ringan menyebabkan janin mengalami peningkatan denyut jantung, tetapi stres yang berat dan lama akan membuat janin menjadi hiperaktif. Akibat lanjut dari gangguan tidur ini adalah depresi dan bayi yang dilahirkan memiliki sedikit waktu tidur yang dalam (Field et al., 2007).

Berdasarkan hal-hal tesebut diperlukan upaya-upaya untuk mengatasi kesulitan tidur ini antara lain dengan olah raga, mengonsumsi obatobatan yang aman bagi ibu hamil, hipnoterapi, edukasi tidur dan latihan relaksasi (Hegard, 2010). Olahraga yang diperuntukkan bagi ibu hamil adalah olah raga yang aman bagi kehamilannya. Jenis olahraga yang paling sesuai untuk ibu hamil adalah senam hamil (Tella et al., 2011).

Secara fisiologis latihan senam hamil berupa relaksasi ini akan menimbulkan efek relaks yang melibatkan syaraf parasimpatis dan sistem syaraf parasimpatis (Wulandari, 2006). Akibat dari hal ini menjadi penurunan detak jantung, irama nafas, tekanan darah, ketegangan otot, tingkat metabolisme dan produksi hormon. Seiring dengan hal ini seluruh badan menjadi lebih sehat, lebih banyak energi, penguatan dan peremajaan (Domin, 2001). Hasil penelitian yang lain juga menunjukkan senam hamil sebagai pelayanan prenatal efektif menurunkan kecemasan (Wulandari, 2006).
Tujuan penelitian ini untuk mengetahui pengaruh senam hamil terhadap durasi tidur ibu hamil dan denyut jantung janin.

\section{METODE PENELITIAN}

Penelitian ini merupakan pre-experimental design, yaitu one group pre-test post-test design, yaitu sebuah desain penelitian yang digunakan dengan cara memberikan tes awal dan tes akhir terhadap kelompok tunggal.

Populasi dalam penelitian ini adalah seluruh ibu hamil yang ada di Puskesmas wilayah Bogor Barat. Sampel pada penelitian ini adalah sebagian ibu hamil trimester ketiga di wilayah Bogor barat. Besar sampel minimal dihitung dengan menggunakan rumus besar sampel penelitian analitis numerik berpasangan, dan didapatkan 12 orang untuk sampel penelitian. Teknik pengambilan sampel dilakukan secara multistage sampling.

Metode senam hamil yang digunakan pada penelitian ini besumber daribuku modul pelatihan pembimbingan senam hamil Pusat pengembangan Kesehatan Carolus (PPKC) (2008). Intervensi senam hamil dilakukan selama 4 minggu lamanya 30 menit. Setelah diberikan perlakuan senam hamil, subjek diberikan post-test untuk mengukur kembali durasi tidur. Pengumpulan data menggunakan instrumen pre-post test tentang senam hamil, data durasi tidur menggunakan instumen Pittsburgh Sleep Quality Index (PSQI). Pengujian normalitas data menggunakan Shapiro-Wilk. Hasil uji normalitas menunjukkan nilai durasi tidur dan denyut jantung janin tidak berdistribusi normal.

\section{HASIL PENELITIAN}

Penelitian ini dilakukan untuk mengetahui adanya pengaruh senam hamil terhadap durasi tidur dan denyut jantung janin. Karakteristik dari responden penelitian antara lain berdasarkan pendidikan terbanyak adalah jenjang pendidikan SMA $(66,6 \%)$. Sebagian besar subjek $(91,7 \%)$ 
merupakan ibu rumah tangga dan paritas terbanyak adalah hamil ke 1 dan ke 2 .

Durasi tidur sebelum senam hamil adalah 6 jam dengan nilai minimum 5 jam dan nilai maksimum 8 jam. Sedangkan nilai median durasi tidur setelah senam hamil adalah 7 jam dengan nilai minimum 6 jam dan nilai maksimum 9 jam.

Pada hasil analisis dengan uji wilcoxon durasi tidur sebelum senam hamil dan durasi tidur setelah senam hamil diperoleh nilai significancy $0,01(\mathrm{p}<0,05)$ Hal ini berarti terdapat perbedaan durasi tidur yang bermakna sebelum dan sesudah senam hamil. Nilai p menunjukkan adanya perbedaan rerata signifikan apabila nilainya $<0,05$. Pada variabel durasi tidur terdapat perbedaan yang signifikan $(\mathrm{p}=0,011)$ antara sebelum dan sesudah senam hamil. Hal ini menunjukan terdapat pengaruh senam hamil terhadap durasi tidur.

Data denyut jantung janin menunjukkan hasil analisis dengan uji wilcoxon data DJJ sebelum dan sesudah senam hamil. Pada hasil analisis, diperoleh nilai significancy $0,008(\mathrm{p}<0,05)$. Hal ini berarti terdapat perbedaan DJJ yang bermakna sebelum dan sesudah senam hamil.

\section{PEMBAHASAN}

Senam hamil merupakan upaya untuk mengatasi kesulitan tidur. Penurunan durasitidur ibu hamil trimester ketiga (28-42 minggu) adalah karena ibu sulit untuk tidur. Hal tersebut dapat membuat kondisi ibu hamil menurun, konsentrasi berkurang, mudah lelah, badan terasa pegal, malas bekerja dan cenderung emosional (Wahyuni, 2013).

Hasil penelitian menunjukkan bahwa senam hamil bermanfaat terhadap peningkatan durasi tidur ibu hamil pada trimester ketiga. Senam hamil sangat membantu mengatasi gangguan tidur ibu selama kehamilan melalui gerakangerakan dan latihan pernafasan dalam senam hamil. Gangguan tidur yang sering dialami oleh ibu hamil adalah penurunan durasi tidur (Wahyuni, 2013). Untuk mengatasi keluhan-keluhan ibu hamil yang dapat mengakibatkan penurunan durasi tidur, maka senam hamil sebagai salah satu pelayanan prenatal, merupakan suatu alternatif terapi yang dapat diberikan pada ibu hamil (Wulandari, 2006). Penelitian yang dilakukan oleh Saint Joseph's University and Delaware Country Memorial Hospital in Drexel Hill, Philadelphia, didapati $97 \%$ ibu hamil trimester III yang mengalami gangguan tidur dapat diatasi dengan olahraga.

Prasetyo (2009) melaporkan hasil penelitian rintisan yang sudah dilakukan Linda $\mathrm{E}$. May, dari Departement of Anatomy di Kansas City University of Medicine and Biosciences melanjutkan penelitian yang melibatkan banyak wanita hamil. Sepuluh orang wanita hamil berpartisipasi dalam penelitian itu, separuhnya melakukan aktivitas fisik yang lain tidak. Gerakan janin seperti bernafas, gerak tubuh dan mulut dimonitor dan direkam selama 24 minggu. Para peneliti menemukan melambatnya irama jantung secara berarti yang terjadi selama para ibu melakukan aktivitas fisik. Sementara irama jantung janin pada para ibu yang tidak banyak beraktivitas justru lebih tinggi.

Para peneliti menemukan melambatnya irama jantung secara berarti yang terjadi selama ibu hamil ini melakukan aktivitas fisik. Sementara irama jantung janin pada ibu hamil yang tidak banyak beraktivitas justru lebih tinggi. Bayi pada ibu yang melakukan olahraga selama kehamilan memiliki jantung yang lebih sehat. Selama berolahraga, terjadi peningkatan jumlah hormonhormon yang mengalir di plasenta termasuk norepinephrine, yang berperan penting dalam perkembangan saraf otonom. Sistem saraf autonomik tersebut mengatur fungsi utama dari tubuh termasuk detak jantung. Keuntungan lain bagi janin dan neonatus dari ibu yang melakukan olahraga adanya toleransi terhadap bermacammacam stresor sebelum dan selama persalinan, 
menurunkan penyimpanan lemak pada akhir kehamilan. Ini terjadi karena adanya pengaruh stimulasi dari olahraga terhadap pertumbuhan ariari (plasenta), aliran darah dan fungsi plasenta (Wijayanti, 2011).

Salah satu manfaat senam hamil adalah relaksasi yang membuat pikiran ibu tenang. Jika seseorang mempunyai pikiran yang tenang maka detak jantungnya akan teratur dan tidak terlalu cepat berbeda dengan ibu yang stress maka detak jantungnya akan cenderung lebih cepat. Ibu dan bayi mempunyai ikatan yang kuat sejak dalam kandungan, apa yang dirasakan ibu maka juga dirasakan oleh janin. Oleh karena itu jika ibu merasa tenang maka janin juga bisa merasakannya dan salah satu responsnya yaitu detak jantungnya melambat tetapi teratur dan kuat (Wijayanti, 2011).

\section{PENUTUP}

Berdasarkan hasil penelitian yang dilakukan dan hasil analisa data yang diperoleh dapat diambil kesimpulan bahwa senam hamil pada ibu hamil trimester III dapat meningkatkan durasi tidur dan berpengaruh terhadap denyut jantung janin.

Berdasarkan hasil penelitian dan beberapa keterbatasan penelitian ini, maka peneliti memberikan saran sebagai berikut: 1) perlu adanya program senam hamil yang rutin dilakukan oleh ibu hamil dalam rangka menjaga kehamilan dan mempersiapkan proses persalinan, 2) adanya penelitian lanjutan dengan metode pendekatan yang berbeda sehingga hasilnya dapat dijadikan rujukan bagi penelitian

\section{DAFTAR PUSTAKA}

Dietz PIN., Williams S.B., Callaghan WM., Bachman DJ., Witlock EP., Hornbrook MC. 2007. Clinically Identified Maternal Depression Before, During, and After Preg- nancies Ending in Live Births. Am J. Psychiatry ; 164:1515-20

Domin, V. 2001. Relaxation How Good Are You at Relaxing?. www.hypnosis update.com

Hegard, Hanna K. 2010. Experience of Physical Activity During Pregnancy in Danish Nuliparous Women with a Physically Active Life Before Pregnancy. A quality Study. BMC Pregnancy and Childbirth, 10 (33)

Kozier E., Berman, S. 2010. Buku Ajar Fundamental Keperawatan : Konsep, Proses \& Praktik. Vol. 1, Edisi : 7. Jakarta : EGC Tella, BA., Sokunbi OG., Akinlami OF., \& Afolabi, B. 2011. Effects Of Aerobic Exercises On The Level Of Insomnia And Fatigue In Pregnant Women. The International Journal of Gynecology and Obstetrics, 15(1).

Wahyuni, N.2013. Pengaruh Senam Hamil Terhadap Perubahan Kadar Hemoglobin (Hb) Pada Kehamilan Trimester Ketiga. Jurnal Kesehatan. 3(2) . 120-128

Wahyuni, N. 2013. Manfaat Senam Hamil Untuk Meningkatkan Durasi Tidur Ibu Hamil. Jurnal Kesehatan Masyarakat. 8(2) 145 152

Wijayanti.2011. Perbedaan Detak Jantung Janin Pada Ibu Hamil Yang Melakukan dan Tidak Melakukan Olahraga Senam Hamil Di SD Mardi Waluyo Kota Blitar Jawa Timur, 2 (4): 183-189

Wulandari P.Y.2006, Efektivitas Senam Hamil sebagai Pelayanan Prenatal dalam Menurunkan Kecemasa Menghadapi Persalinan Pertama. INSAV. 8 (2) -144

Venkata C, and Venkatashiah S.B 2009. Sleep Disordered Breathing During Pregnancy. The Journal of the American Board of Family Medicine, 22(2)-158-168. 